\title{
THE EFFECT OF THE PRESENCE OF MUSCLE TISSUE IN A BONE HEALING SITE
}

\author{
Andy Petroianu, Renato Abranches Corsetti and Luiz Ronaldo Alberti
}

PETROIANU A et al. The effect of the presence of muscle tissue in a bone healing site. Rev. Hosp. Clín. Fac. Med. S. Paulo 59(4):193-197, 2004.

PURPOSE: The recovery of a bone fracture is a process that is not yet fully understood. The literature conflicts on the results obtained by the interposition of foreign tissue inside a damaged bone. The objective of the present study was to ascertain the effect of placing muscle tissue between the stumps of a fractured bone.

METHOD: The study was carried out on 10 rabbits divided into 2 groups $(\mathrm{n}=5)$ : Group 1 -partial fracture of the humerus and interposition of muscle tissue; Group 2-complete fracture of the humerus and interposition of muscle tissue. The fractured limb of all animals was immobilized for 8 weeks. At the end of this time, the rabbits were killed and their operated humeri were carefully removed for roentgenological and histological assessment.

RESULTS: All humeri of Group 1 recovered their integrity and normal aspect. However, the healing of the humeri of Group 2 was not perfect. Gross angulation of the bone diaphysis occurred in all animals, and immature trabecular bone, osteochondral tissue, and persistence of muscle tissue substituted normal bone.

CONCLUSIONS: Interposed muscle does not affect partial bone fracture healing but causes instability in a complete fracture.

KEY WORDS: Bone. Fracture. Muscle interposition. Healing. Rabbit.

Numerous methods have been developed in an attempt to stimulate osteogenesis in disturbed bone healing processes. ${ }^{1}$ The most common has been the implantation of fresh autogenous bone grafts harvested from the ribs, iliac crest, or anterior tibia. ${ }^{2-4}$ Other methods use bone powder implants ${ }^{5}$ or various commercially available allografts ${ }^{6,7}$ and different substances containing calcium phosphates. ${ }^{8-10}$ In the recent years, studies have been concentrated on the osteogenic potential of demineralized bone powder implants. ${ }^{11-16}$ These techniques have varying rates of success, but bone nonunion is still a major problem in clinical practice. ${ }^{17}$

Little basic research has been done on the impact of different factors related to disturbed osteogenesis. ${ }^{18} \mathrm{Sev}$ eral factors that affect fracture healing have been described, such as failure of limb immobilization and consequent instability of the fracture, insufficient blood circulation, and low tissue oxygen tension at the fracture site. Other factors are the size of the tissue defect that appears after the primary injury, deprivation of neural elements (e.g. diabetic neuropathy), nutritional status, infection, and interposition of soft

From the Department of Surgery of the Medical School of the Federal University of Minas Gerais - Belo Horizonte/MG, Brazil. E-mail: petroian@medicina.ufmg.br Received for publication on February 18, 2004. tissue, including muscle tissue. ${ }^{19,20}$ Some authors share the opinion that by far the most important factor in the process of bone repair is the success in the immobilization of the fractured limb and stability of the fracture..$^{21-23}$

Investigations are not totally clear about the effect of muscle tissue interposition in a bone healing site. Ray ${ }^{24}$ considers interposition of soft tissues in a fracture gap to be a normal event. Alter et al. ${ }^{25}$ found that bone healing does not occur in dogs when interposing muscle tissue is maintained between the bone stumps, even in stable fractures after 5 months. The nonunion of fractures was determined by radiological and histological examination. Therefore, the presence of muscle tis- 
sue in a fracture healing site is considered as one of the causes of delayed healing or nonunion fractures. However, Skallarides ${ }^{26}$ used a segment of muscle to fill a bone cavity formed after a sequestrotomy, and bone healing occurred without any problem. Jarry and Uhthoff ${ }^{27}$ tried to produce pseudoarthrosis by interposing muscle tissue between the stumps of a long bone fracture, but no arthropathy was obtained and bone healing was uneventful.

In view of the controversy in the literature, the present study was undertaken to assess the effect of the presence of muscle tissue in a bone healing site under 2 different conditions: partial and complete fracture of the humerus.

\section{METHOD}

This investigation followed the International Rules for Protection of Animals and was approved by the Ethic Commission of the Department of Surgery of our Institution. ${ }^{28,29}$

The experiment was conducted on 10 New Zealand White rabbits of both genders (5 males and 5 females). The animals were 75 days old, and their average weight was $1515 \pm 94$ grams. The surgical procedures were done under intramuscular anesthesia with 40 $\mathrm{mg} / \mathrm{kg}$ ketamine hydrochloride $\left(\right.$ Ketalar $\left.^{\grave{\partial}}\right)$. After skin shaving and local antisepsis with Polividine ${ }^{\grave{O}}(10 \%$ polyvinyl polvidone iodine solution), a $4 \mathrm{~cm}$ longitudinal incision was made on the lateral side of the right arm. The humerus was completely dissected by separating the arm muscles. Next, 2 different approaches were followed according to the design described below:

Group 1 ( $\mathrm{n}=5,2$ males and 3 females): an osteotome was used to cut the humerus in a partial section, and a segment of muscle with its intact vascular supply was introduced into the defect and fixed with 4-0 nylon thread.

Group 2 ( $\mathrm{n}=5,3$ males and 2 females): the humerus diaphysis was completely cut with an osteotome. A segment of muscle with its intact vascular supply was introduced between the 2 bone stumps and sutured with 40 nylon thread.

The operated limb was immobilized with cotton strips that surrounded the rabbit's fractured limb and the thorax. The animals were given regular rabbit food and water ad libitum.

All animals were followed for 8 weeks and were then killed under ketamine anesthesia and by excess ether inhalation. The fractured humerus of each rabbit was removed and trimmed of excess surrounding soft tissue, and macroscopic and microscopic studies were carried out. Each humerus was fixed in $10 \%$ buffered formalin, demineralized in nitric acid, embedded in paraffin, and cut; the sections were stained with hematoxylin and eosin for histological study. A roentgenographic record was obtained for each specimen. Evaluation of fracture healing was based on roentgenographic and histological examination. ${ }^{30}$ According to Allen et al., ${ }^{31}$ the degree of fracture repair may be classified with a 5-point scale:

- Grade 0: The formation of pseudoarthrosis with a cavity containing blood or other fluid within the cartilaginous plate between fracture fragments;

- Grade 1: incomplete cartilaginous union with retention of fibrous elements in the cartilaginous plate;

- Grade 2: complete cartilaginous union characterized by a wellformed plate of hyaline cartilage joining the fragments;

- Grade 3: incomplete bone union characterized by the presence of a small amount of cartilage in the callus;

- Grade 4: complete bone union; Based on the radiological study, the bone was considered healed when no gap or cavity was found and crosstrabeculation with mature consolidation of the periosteal callus was present.

\section{RESULTS}

No death occurred during the experimental period. All animals had a mean increase in weight to $1893 \pm 133$ grams.

In all rabbits of Group 1, the humeri presented complete macroscopic, histological, and radiological recovery of the bone defect (grade 4 on the Allen et al. scale), with minimal angulation of the humerus. The gap in the middle of the bone was filled with mature bone tissue, and the medullary cavity presented a normal histological aspect (Figure 1a). The periosteum near the healing site developed intense fibrovascular neoformation, forming a thick callus. No difference was observed between the two genders.

In Group 2, healing was delayed in 4 animals with incomplete bone union (grade 3 on the Allen et al. scale). Only 1 female rabbit presented complete recovery with perfect bone union (grade 4 on the Allen et al. scale). However, all bones had gross angulation at the scar level (Figure 1b). The humerus with complete healing presented mature tissue with a normal medullary space. The other 4 rabbits developed osteochondral tissue and immature trabecular bone between the stumps and in the middle of the medullary space. In 2 male rabbits, muscle tissue surrounded by osteochondral tissue was still present. No difference was observed between the two genders.

\section{DISCUSSION}

Understanding bone healing and the factors that may interfere with re- 

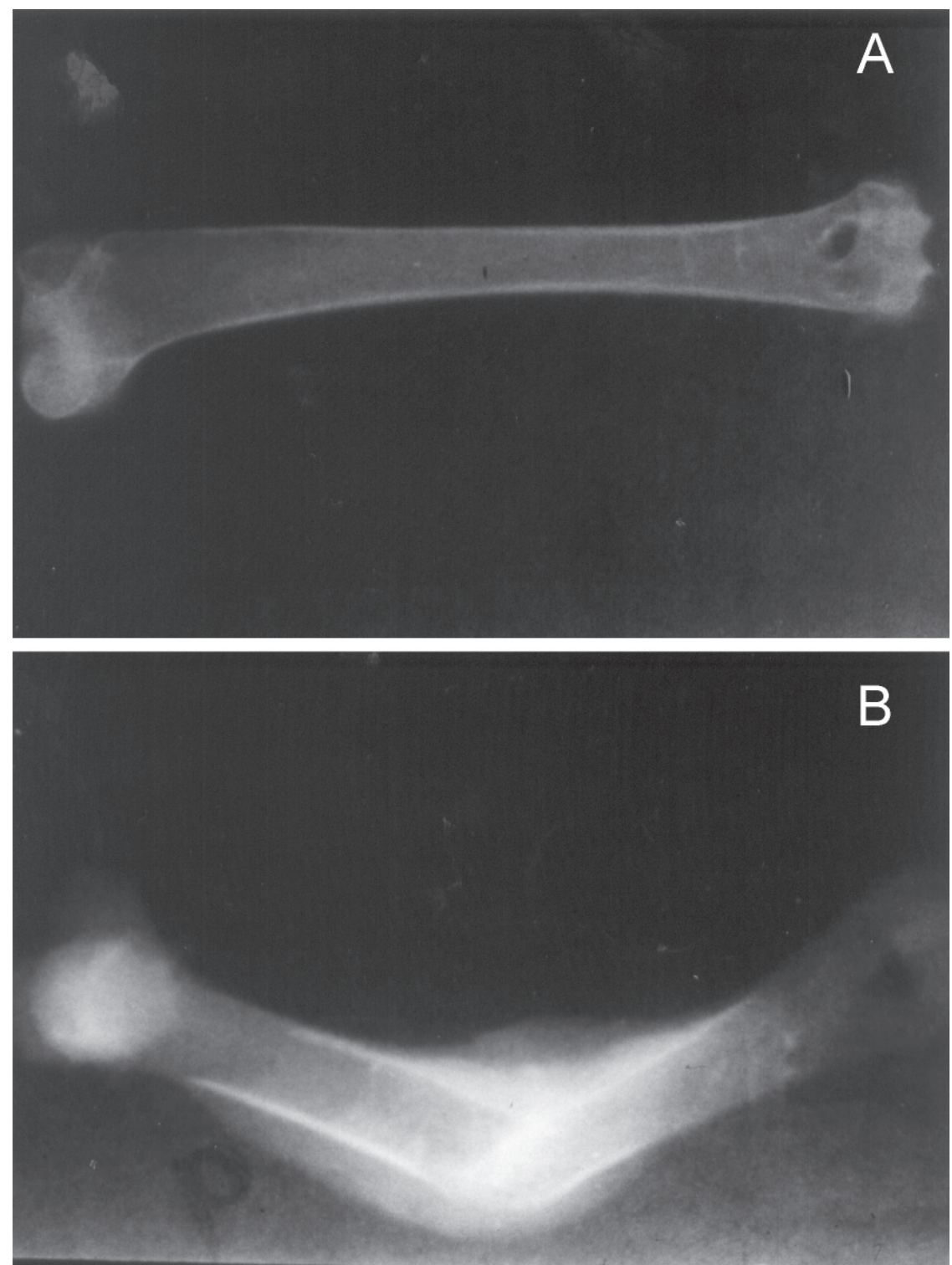

Figure 1 - Roentgenography of the humerus showing complete healing 8 weeks after fracture and interposition of muscle tissue. A- Partial fracture. Observe the integrity of the bone. B- Complete fracture. Observe the bone angulation of the diaphysis at the level of the section.

covery after a trauma are still medical challenges. Animals of both genders were used to ascertain any gender differences related to bone healing. The present results do not differ from those reported in the literature, which also do not show gender to be a pivotal factor in bone healing. ${ }^{10,15,18,25}$

The period of 8 weeks of the present study was based on the time necessary for a complete bone recovery in rabbits according to the litera- ture ${ }^{17,30,31}$. This time does not take into account the impairment of the scar process provoked by agents such as the interposition of foreign tissue in the middle of the bone.

Bone healing occurred in both groups, having partial and complete fractures. However, the scar was well constituted (grade 4 on the scale of Allen et al.) only in the animals with partial fracture. The osteochondral or cartilage tissue observed at the frac- ture site and the partial recovery of the medullary space after 8 weeks indicate delayed healing probably due to the interposed muscle. The Allen scale is an adequate tool for classifying the final result of fracture repair and establishing the efficacy of treatment.

A large muscle mass present in the middle of a fractured bone plays the role of a large barrier that may be immediately incorporated into the healing process of a long bone. This foreign tissue led to instability of the fracture and might have contributed to the angularity of the bones in Group 2. It is also worth supposing that the imperfect immobilization of the humerus during the healing process is responsible for the imperfect bone healing. It is well known that immobilization is fundamental for the healing of bone fractures. ${ }^{2,5,17,21,23,30}$ As shown by other authors, when immobilization fails, the union of bone stumps is less stable and the angularity at the level of the scar is very frequent. ${ }^{1,5,7,15,18,19,21-25,27,30}$ Thus the healing defect may be due to ineffective immobilization more than to interposition of the muscle tissue. No sign of metabolic or nutritional disturbances that might interfere with bone healing was detected in any animal.

In conclusion, the interposition of muscle tissue in the middle of a partially fractured bone does not prevent its perfect healing. However, in the presence of a complete fracture, the muscle tissue leads to bone instability, and imperfect immobilization may provoke angulation of the bone scar.

\section{ACKNOWLEDGMENT}

The authors thank the Radiology Unit of the Hospital of Clinics, Federal University of Minas Gerais, for the radiologic studies of the bones. We also acknowledge CNPq and FAPEMIG for financial support. 
PETROIANU A e col. A influência da presença de tecido muscular em local de cicatrização óssea. Rev. Hosp. Clin. Fac. Med. S. Paulo 59(4):193-197, 2004.

OBJETIVO: A recuperação de uma fratura óssea ainda não está bem compreendida. A literatura é controversa quanto aos resultados da interposição de tecidos no interior de uma lesão óssea. O objetivo do presente trabalho foi verificar o efeito da interposição de tecido muscular entre as partes de um osso fraturado.
MÉTODO: Dez coelhos foram distribuídos em dois grupos $(n=5)$ : Grupo 1- secção parcial do úmero e interposição de tecido muscular; Grupo 2secção completa do úmero e interposição de tecido muscular. Os membros fraturados de todos os animais foram imobilizados por oito semanas. No final desse período, os coelhos foram mortos e o úmero fraturado foi cuidadosamente removido para estudo radiográfico e histológico.

RESULTADOS: Todos os úmeros do Grupo 1 recuperaram sua integridade e se apresentaram de aspecto nor- mal. Entretanto, o processo de recuperação do Grupo 2 não foi perfeito. Angulações grosseiras da diáfise óssea ocorreram em todos os animais, e o osso normal foi substituído por trabéculas ósseas imaturas, tecido osteochondral e se caracterizaram pela persistência do tecido muscular.

CONCLUSÕES: A interposição de tecido muscular não afeta o processo cicatricial de fraturas parciais, mas torna instável a fratura completa.

UNITERMOS: Osso. Fratura. Interposição muscular. Cicatrização. Coelho.

\section{REFERENCES}

1. Simion M, Dahlin C, Trisi P, Piattelli A. Qualitative and quantitative comparative study on different filling materials used in bone tissue regeneration. Int J Periodontics Restorative Dent 1994;14:198-215.

2. Boyne PJ. Autogenous cancellous bone and marrow transplants. Clin Orthop 1970;73:199-209.

3. Taylor GI. The current status of free vascularized bone grafts. Clin Plast Surg 1983;10:185-209.

4. Schaberg SJ, Petri WH, Gregory EW, Auclair PL, Jaco E. - A comparison of freeze-dried allogeneic and fresh autologous vascularized rib grafts in dog radial discontinuity defects. J Oral Maxillofac Surg 1985;43:932-7.

5. Shehadi SI. External fixation of metacarpal and phalangeal fractures. J Hand Surg 1991;16:544-550.

6. Pribaz JJ, Weiss DD, Mulliken JB, Eriksson E. Prelaminated free flap reconstruction of complex central facial defects. Plast Reconstr Surg 1999;104:357-65.

7. Cheline AJ, Reddi AH, Martin RB. Bone morphogenetic protein7 selectively enhances mechanically induced bone formation. Bone 2002;31:570-4.

8. Gongloff RK. Alveolar ridge augmentation with collagen tubes containing bone and hydroxylapatite. Int J Oral Maxillofac Surg 1992;21:12-6.

9. Misiek DJ. Vascularized free bone grafts for maxillary and mandibular reconstruction. Atlas Oral Maxillofac Surg Clin North Am 1994;2:123-40.

10. Thomas KA, Cook SD, Haddad RJ Jr, Kay JF, Jarcho M. Biologic response to hydroxylapatite-coated titanium hips. A preliminary study in dogs. J Arthroplasty 1989;4:43-53.
11. Johnson EE, Urist MR. Human bone morphogenetic protein allografting for reconstruction of femoral nonunion, Clin Orthop 2000;371:61-74

12. Vinall RL, Lo SH, Reddi AH. Regulation of articular chondrocyte phenotype by bone morphogenetic protein 7 , interleukin 1 , and cellular context is dependent on the cytoskeleton. Exp Cell Res 2002;272:32-44.

13. Davis JL, Jeansonne BG, Davenport WD, Gardiner D. The effect of irrigation with doxycycline or citric acid on leakage and osseous wound healing. J Endod 2003;29:31-5.

14. Mizuno S, Tateishi T, Ushida T, Glowacki J. Hydrostatic fluid pressure enhances matrix synthesis and accumulation by bovine chondrocytes in three-dimensional culture. J Cell Physiol 2002;193:319-27.

15. Eid K, Zelicof S, Perona BP, Sledge CB, Glowacki J. Tissue reactions to particles of bone-substitute materials in intraosseous and heterotopic sites in rats, discrimination of osteoinduction, osteocompatibility, and inflammation. J Orthop Res 2001;19:962-9.

16. Huard J, Li Y, Peng H, Fu FH. Gene therapy and tissue engineering for sports medicine. J Gene Med 2003;5:93-108.

17. Oni A - The bony callus. Injury 1997;28:629-31.

18. Hietaniemi K, Peltonen J, Paavolainen P. An experimental model for non-union in rats. Injury 1995;26:681-6.

19. Frost HM. Should future risk-of-fracture analyses include another major risk factor? J Clin Densitom 2001;4:381-3.

20. Szczesny G. Molecular aspects of bone healing and remodeling. Pol J Pathol 2002;53:145-53. 
21. WANG GJ, DUNSTAN JC, REGER SI et al. - Experimental femoral fracture immobilized by rigid and flexible rods. Clin Orthop 1981; 154: 286-90.

22. Wang GJ, Dunstan JC, Reger SI, Hubbard S, Dillich J, Stamp WG. Poor muscle coverage delays fracture healing in rats. Acta Orthop Scand 2002;73:471-4.

23. Molster A, Gjerdet NR, Raugstad TS, Hvidsten K, Alho A, Bang G. Effect of instability of experimental fracture healing. Acta Orthop Scand 1982;53:521-6.

24. Ray RD - Osseous grafts and implants. Rev Chir Orthop Reparatrice Appar Mot 1974;60:7-20.

25. Altner PC, Grana L, Gordon M. An experimental study on the significance of muscle tissue interposition on fracture healing. Clin Orthop 1975;111:269-73.

26. Skallarides HT. Extensive giant-cell tumor of the lower end of the radius. Clin Orthop 1965;42:151-16.
27. Jarry L, Uhthoff HK. Differences in healing of metaphyseal and diaphyseal fractures. Can J Surg 1971;14:127-35.

28. Cooper JE. Ethics and laboratory animals. Vet Rec 1985;116:5945.

29. Petroianu A. Pesquisa experimental - In: PETROIANU A - Ética, Moral e Deontologia Médicas. $1^{\text {st }}$ ed. Rio de Janeiro, Guanabara Koogan, 2000. p. 185-90.

30. Iacobellis C, Cacciato F. Aseptic nonunion and delay in consolidation in the tibia. Chir Organi Mov 2001;86:199210 .

31. Allen HL, Wase A, Bear WT. Indomethacin and aspirin: effect of nonsteroidal anti-inflammatory agents on the rate of fracture repair in the rat. Acta Orthop Scand 1980; 51:595-600. 